\title{
Fabrikasi Sensor Elektrokimia Berbasis Karbon dan Nanopartikel Perak (NPAg) Untuk Mendeteksi Acetaminophen
}

\author{
Nurafni Julianti ${ }^{* 1}$, Roberth Victoria Manurung ${ }^{2}$, Arifin $^{3}$ \\ ${ }^{1,3}$ Departemen Fisika, Fakultas Matematika dan Ilmu Pengetahuan Alam, Universitas \\ Hasanuddin, Indonesia \\ ${ }^{2}$ Kampus LIPI, Bandung, Indonesia \\ e-mail: ${ }^{* 1}$ nurafnijulianti01@gmail.com, ${ }^{*} *^{2}$ rvmanurung@gmail.com, \\ *3arifinpide@gmail.com.
}

\begin{abstract}
Abstrak
Acetaminophe (paracetamol) merupakan salah satu obat analgesik yang paling banyak digunakan terutama untuk penahan rasa sakit atau nyeri. Kelebihan acetaminophen bagi tubuh manusia akan berdampak buruk bagi kesehatan salah satunya kerusakan pada organ hati. Pada penelitian ini, nanopartikel perak (NPAg) disintesis menggunakan metode Turkevich untuk meningkatkan konduktivitas atau laju elektron transfer pada permukaan karbon. Sehingga sensitivitas dari sensor elektrokimia untuk acetaminophen dapat ditingkatkan. Dalam pengujian kestabilan dilakukan tiga buah sampel dari elektroda referensi $\mathrm{Ag} / \mathrm{AgCl}$ masingmasing diperoleh dengan rentang tegangan $10-30 \mathrm{mV}, 0,94-35 \mathrm{mV}$, dan $20-67 \mathrm{mV}$. Secara umum kinerja elektroda referensi $\mathrm{Ag} / \mathrm{AgCl}$ dapat dikatakan cukup stabil dengan tegangan < $100 \mathrm{mV}$. Dari data uji sampel acetaminophen puncak oksidasi terjadi pada rentang tegangan 0,2 - 0,4 mV dan arus yang dihasilkan meningkat secara signifikan. Hasil karakterisasi menggunakan SEM morfologi permukaan NPAg mempunyai pori yang kecil disebabkan karena ukuran partikel yang besar. Sedangkan karakterisasi menggunakan FTIR menghasilkan empat macam gugus fungsi diantaranya gugus fungsi $\mathrm{C}-\mathrm{O}, \mathrm{C}-\mathrm{H}, \mathrm{NO}_{2}$, dan $\mathrm{N}-\mathrm{H}$.
\end{abstract}

Kata kunci-Nanopartikel perak, Acetaminophen, Karbon.

\begin{abstract}
Acetaminophen (paracetamol) is one of the most heavily used analgesic drugs especially for pain or pain relief. The excess of acetaminophen for the human body produces a bad effects, one of them is a liver disease. In this study, silver nanoparticle (NPAg) is synthesized using Turkevich methods to increase the conductivity or the rate of transfer electron in the carbon's surface. So, the sensitivity from electrochemical sensors to acetaminophen can be enhanced. The stability test was done by three samples from $\mathrm{Ag} / \mathrm{AgCl}$ reference electrodes, each of them is $10-30 \mathrm{mV}, 0,94-35 \mathrm{mV}$, and $20-67 \mathrm{mV}$. Generally, the performing of $\mathrm{Ag} / \mathrm{AgCl}$ refrence elecrodes can be concluded as fairly stable with voltage less than $100 \mathrm{mV}$. From the data acetaminophen sample test, the peak of oxidation happens on 0,2-0,4 $\mathrm{mV}$ session, and the current produced increased significantly. The results of characterization using SEM morphology in NPAg have a smaller pores because of the size of the partical is also big. While the characterization using FTIR produces four kinds of functional groups including $C-O$, $\mathrm{C}-\mathrm{H}, \mathrm{NO2}$, and $\mathrm{N}-\mathrm{H}$ functional groups.
\end{abstract}

Keywords-Silver nanoparticles, Acetaminophen, Carbon. 


\section{PENDAHULUAN}

Acetaminophen (paracetamol) merupakan obat analgesik yang paling banyak digunakan oleh manusia sebagai penghilang rasa sakit atau nyeri. Akan tetapi, kelebihan mengkonsumsi acetaminophen berdampak buruk bagi kesehatan salah satunya kerusakan pada hati [1]. Nanopartikel perak merupakan produk yang berbasis nanoteknologi yang dapat diaplikasikan sebagai katalis dan detektor dengan rumus kimia NPAg. [2,3]. Perkembangan nanopartikel perak menjadi pusat perhatian para peneliti sampai saat ini, karena memiliki sifat fisika, biologi dan kimia yang unik yang dapat digunakan dalam bidang industri, kosmetik, serta kedokteran sebagai detektor $[4,5]$. Ukuran NPAg berpengaruh dalam penentuan sifat optik, listrik, magnet, dan anti bakterinya, semakin besar efek anti-bakterinya maka semakin kecil ukuran partikelnya [6,7]. Salah satu keunggulan pembuatan NPAg yaitu relatif mudah untuk diproduksi, dan harganya yang cukup murah serta ramah lingkungan [8].

Berbagai metode sintesa untuk memproduksi NPAg seperti yang dilakukan oleh Masakke, dkk (2015) yaitu metode fisika atau biasa dikenal dengan top-down dan metode kimia atau biasa dikenal dengan bottom-up [7]. Akan tetapi, metode tersebut menimbulkan berbagai masalah seperti penggunaan zat pelarut beracun, mengeluarkan limbah berbahaya dan konsumsi energi yang tinggi. Khairy, dkk (2018) meneliti tentang bagaimana cara mengetahui kadar acetaminophen dengan memanfaatkan ceriumoxide NP yang dimodifikasi [9]. Akan tetapi, membutuhkan waktu yang cukup lama untuk memperoleh hasil pengujian dan berbiaya mahal.

Teknologi film tebal merupakan bagian dari proses fabrikasi elektroda dengan menggunakan metode Screen Printed Carbon Electrode (SPCE), dengan ketebalan 5-20 $\mu \mathrm{m}$. Salah satu kelebihan dari teknologi film tebal yaitu mempunyai lapisan yang stabil pada tegangan yang lebih tinggi dibandingkan teknologi film tipis. Teknologi film tebal juga dapat dijadikan sebagai konduktor dari sensor [10].

Pada penelitian ini akan dilakukan fabrikasi elektroda sensor elektrokimia untuk mendeteksi acetaminophen. Adapun metode yang digunakan adalah teknologi film tebal yang merupakan salah satu teknik pengujian yang cukup efektif karena dapat memproduksi dengan waktu yang cukup cepat serta mudah untuk diproduksi. Dengan memanfaatkan NPAg dalam fabrikasi elektroda sensor elektrokimia diharapkan untuk meningkatkan konduktivitas pada permukaan elektroda kerja yaitu karbon.

\section{METODE PENELITIAN}

\subsection{Alat dan Bahan}

Alat yang digunakan pada penelitian ini, yaitu screen printing de haast, ultrasonic cleaner DELTA 318H, screen maker 300TT, magnetik stirer, timbangan anaytical balance, Radiant Technology Corporation (RTC), CorrTest Electrochemical Workstation, SEM dan FTIR.

Bahan yang digunakan pada penelitian ini, yaitu $\mathrm{AgPd}, \mathrm{AgNO}_{3}$, ulano 133, $\mathrm{Ag}$, $\mathrm{C}_{6} \mathrm{H}_{5} \mathrm{O}_{7} \mathrm{Na}_{3}$, karbon, pasta bahan elektrik, larutan $\mathrm{KFeCN}$, Pt dan larutan nanopartikel perak (NPAg).

\subsection{Prosedur Penelitian}

\subsubsection{Fabrikasi Elektroda}

Proses fabrikasi elektroda sensor elektrokimia menggunakan metode teknologi film tebal terbagi atas 2 tahap yaitu tahap perencanaan dan tahap pembuatan. Pada tahap perencanaan yang dilakukan yaitu mendesain keramik, kaki elektroda, elektroda referensi, elektroda kerja, elektroda bantu, dan enkapsulasi elektroda. Adapun software yang digunakan

IJEIS Vol. 10, No. 1, April 2020 : $31-40$ 
untuk mendesain adalah CoredDraw X7. Sedangkan untuk tahap pembuatan ditunjukkan pada Gambar 1.

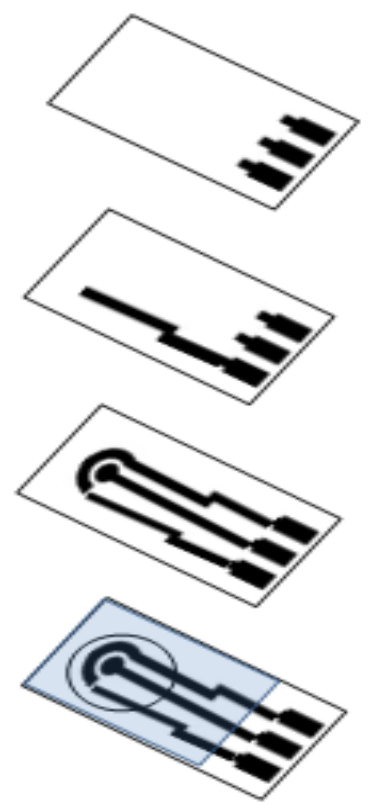

Langkah 1. Pencetakan kaki elektroda menggunakan pasta AgPd.

Langkah 2. Pencetakan elektroda referensi menggunakan pasta Ag.

Langkah 3. Pencetakan elektroda kerja dan elektroda bantu menggunakan pasta karbon.

Langkah 4. Pencetakan enkapsulasi elektroda menggunakan pasta bahan elektrik.

Gambar 1. Skema fabrikasi elektroda sensor elektrokimia.

Setelah proses tahap pencetakan seperti yang ditunjukkan pada Gambar 1. Selanjutnya dilakukan pembakaran atau firing elektroda sensor elektrokimia. Tujuan dari pembakaran yaitu membuat pasta yang telah dicetak pada keramik menjadi permanen sehingga ketika melakukan pembersihan pada elektroda sensor elektrokimia pasta tersebut tidak akan luntur. Setelah itu melakukan pemotongan atau finalisasi pada elektroda sensor elektrokimia yang telah dibuat.

\subsubsection{Sintesis NPAg}

Proses sintesis nanopartikel perak dilakukan dengan metode Turkevich. Menyiapkan 3,6 mg padatan $\mathrm{AgNO}_{3}$, kemudian tambahkan air suling sebanyak $20 \mathrm{~mL}$ ke dalam gelas beker 100 $\mathrm{mL}$, kemudian stirer selama 10 menit dengan suhu $75^{\circ} \mathrm{C}$ dan putaran $6 \mathrm{rpm}$. Sementara distirer siapkan padata sodium citrate sebanyak $50 \mathrm{mg}$, kemudian tambahkan air suling sebanyak $5 \mathrm{~mL}$, gunakan alat cleaner delta $318 \mathrm{H}$ untuk melarutkan sodium citrate dengan air suling. Setelah larut tambahkan sodium citrate ke dalam larutan $\mathrm{AgNO}_{3}$ setiap 1 menit sebanyak $1 \mathrm{~mL}$. Setelah itu strirer kembali larutan dengan waktu 10 menit. Setelah distirer diamkan pada suhu ruang selama 1 jam, setelah dingin simpan di lemari pendingin dan larutan siap untuk digunakan.

\subsubsection{Uji Stabilitas Elektroda Referensi Ag/AgCl}

Ditambahkan $10 \mathrm{~mL} \mathrm{KCl}$ dengan konsentrasi $2 \mathrm{M}$ ke dalam gelas beker $50 \mathrm{~mL}$ dihubungkan elektroda referensi $\mathrm{Ag} / \mathrm{AgCl}$ dengan elektroda pabrikan pada multimeter. Masukkan ke dalam gelas beker yang berisi larutan $\mathrm{KCl}$ dengan konsentrasi $2 \mathrm{M}$, elektroda referensi $\mathrm{Ag} / \mathrm{AgCl}$ dan elektroda pabrikan, kemudian amati grafik yang muncul pada komputer.

\section{HASIL DAN PEMBAHASAN}

\subsection{Fabrikasi Elektroda}

Fabrikasi elektroda sensor elektrokimia dilakukan dengan menggunakan metode teknologi film tebal. Dengan konfigurasi tiga elektroda yaitu working electrode (elektroda kerja), reference electrode (elektroda referensi) dan counter electrode (elektroda bantu). 
Software yang digunakan untuk mendesain elektroda sensor elektrokimia adalah CorelDRAW X7. Gambar 2 menunjukkan hasil dari fabrikasi elektroda sensor elektrokimia.

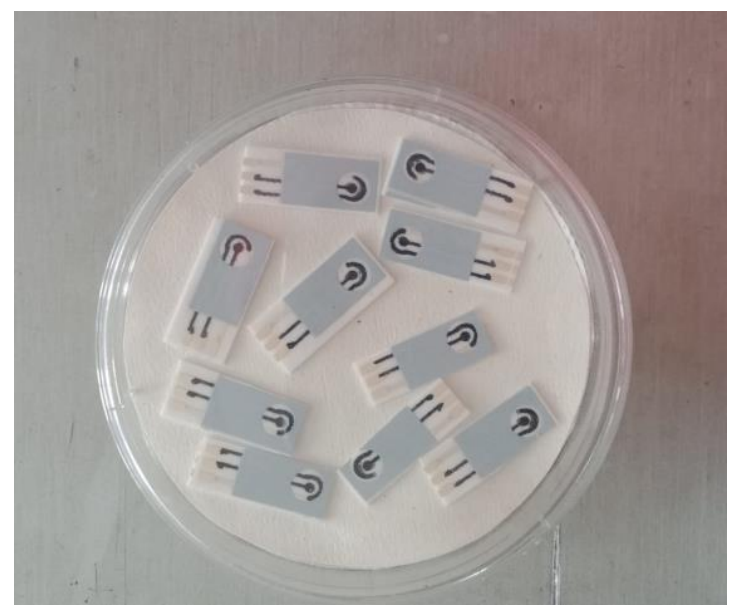

Gambar 2. Hasil fabrikasi elektroda sensor elektrokimia.

Pada proses fabrikasi elektroda sensor elektrokimia menghasilkan 10 buah elektroda sensor elektrokimia dengan perlakuan yang sama. Adapun pasta yang digunakan pada elektroda kerja dan elektroda bantu adalah pasta karbon, karena karbon bersifat inert dan tidak mengalami reaksi yang dapat mengganggu ketika melakukan pengukuran. Sedangkan, pasta yang digunakan untuk elektroda referensi adalah perak (Ag), karena $\mathrm{Ag}$ bersifat stabil dan mempunyai konduktivitas yang tinggi diantara seluruh logam [11].

\subsection{Hasil Pengujian dan Karakterisasi}

\subsubsection{Kestabilan Elektroda Referensi}

Pengujian kestabilan elektroda referensi $\mathrm{Ag} / \mathrm{AgCl}$ dilakukan dengan tujuan untuk mengetahui tegangan yang dihasilkan oleh elektroda referensi stabil atau tidak. Gambar 3 menunjukkan grafik kestabilan dari tiga elektroda sensor elektrokimia. Faktor kestabilan sangatlah berpengaruh terhadap pengujian yang menggunakan siklik voltametri dengan konfigurasi tiga elektroda. Adapun pengujian yang dilakukan yaitu membandingkan tegangan elektroda pabrikan terhadap tegangan yang dihasilkan oleh elektroda referensi $\mathrm{Ag} / \mathrm{AgCl}$ melalui proses potensiometri menggunakan larutan elektrolit berupa $\mathrm{KCl}$ dengan konsentrasi $2 \mathrm{M}$.

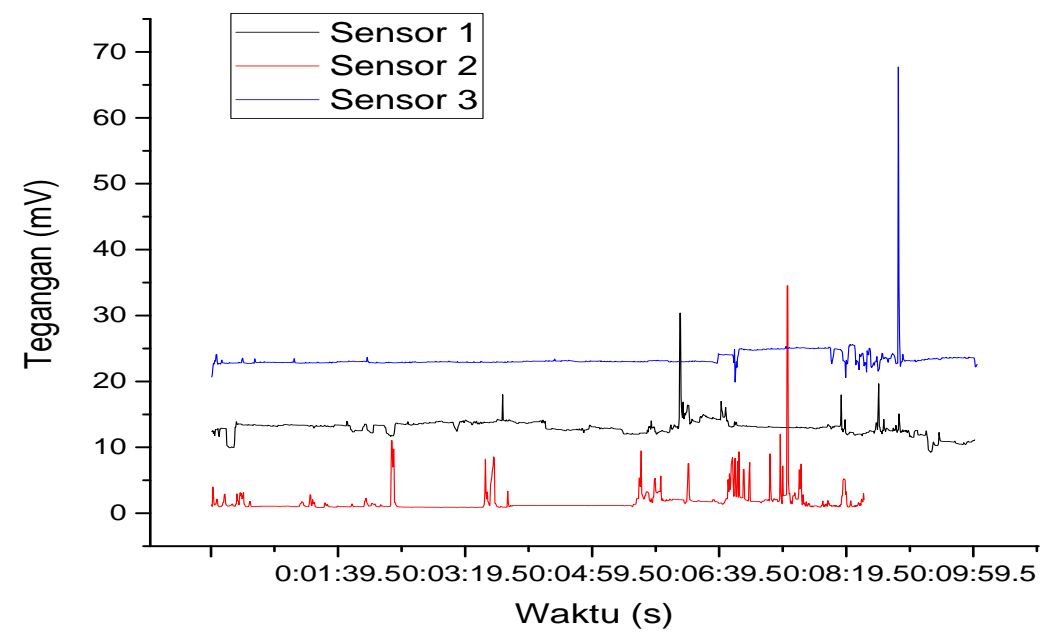

Gambar 3. Hasil uji kestabilan elektroda referensi $\mathrm{Ag} / \mathrm{AgCl}$ dengan $\mathrm{KCl} 2 \mathrm{M}$. 
Dalam proses ini telah dilakukan pengujian tiga buah sampel dari elektroda referensi dengan beda potensial yang diperoleh. Rentang tegangan yang dihasilkan masing-masing sensor secara berurut yaitu pada rentang $10-30 \mathrm{mV}, 0,94-35 \mathrm{mV}$ dan $20-67 \mathrm{mV}$. Rentang waktu pengujian yang dilakukan selama \pm 10 menit. Berikut merupakan grafik yang menunjukkan kestabilan dari elektroda referensi $\mathrm{Ag} / \mathrm{AgCl}$. Dari data tersebut memperlihatkan bahwa elektroda referensi $\mathrm{Ag} / \mathrm{AgCl}$ yang telah dibuat memiliki tingkat kestabilan yang cukup baik dengan tegangan $<100 \mathrm{mV}$ [12]. Apabila tegangan yang dihasilkan $>100 \mathrm{mV}$ maka sensor tersebut tidak layak digunakan karena, pada saat pengujian sampel sensor tidak dapat bekerja dengan baik atau memunculkan banyak noise.

\subsubsection{Hasil Uji Sampel Acetaminophen}

Pengujian sampel acetaminophen dengan berbagai variasi konsentrasi dilakukan dengan menggunakan siklik voltametri dalam larutan $\mathrm{KCl}$ 0,1 $\mathrm{M}$ dan KFeCN $2 \mathrm{mM}$. Pada Gambar 4 menunjukkan hasil uji sampel acetaminophen dengan berbagai konsentrasi.

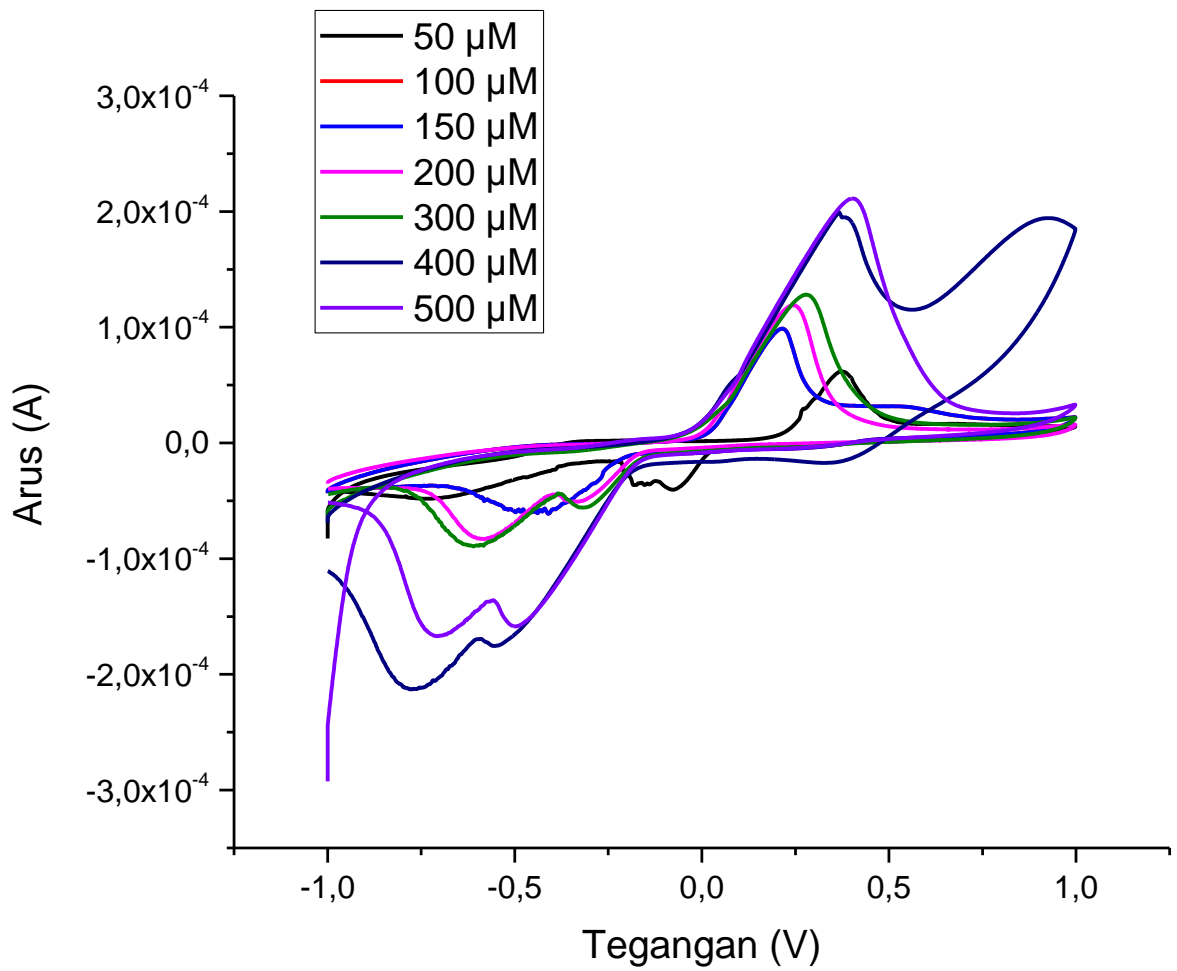

Gambar 4. Siklik voltametri acetaminophen dalam larutan KCL 0,1 M dan KFeCN 2 mM.

Pengujian acetaminophen dengan variasi konsentrasi menggunakan NPAg dilakukan pada rentang tegangan -1 hingga $1 \mathrm{~V}$ dengan laju pindai $100 \mathrm{mV} / \mathrm{s}$. Dapat dilihat pada Gambar 4. peak reaksi oksidasi muncul dengan konsentrasi $50 \mu \mathrm{M}$ pada tegangan $0,3 \mathrm{~V}$ dengan arus yang dihasilkan sebesar $0,05 \times 10^{-4} \mathrm{~A}$. Pada konsentrasi $100 \mu \mathrm{M}$ peak reaksi oksidasi muncul pada tegangan $0,25 \mathrm{~V}$ dengan arus yang dihasilkan sebesar $1,0 \times 10^{-4} \mathrm{~A}$. Sehingga dapat diperhatikan penambahan larutan NPAg pada elektroda kerja sensor elektrokimia berpengaruh terhadap peningkatan arus yang dihasilkan $[11,13]$. Gambar 5 menunjukkan hubungan antara konsentrasi sampel dan arus yang dihasilkan. 


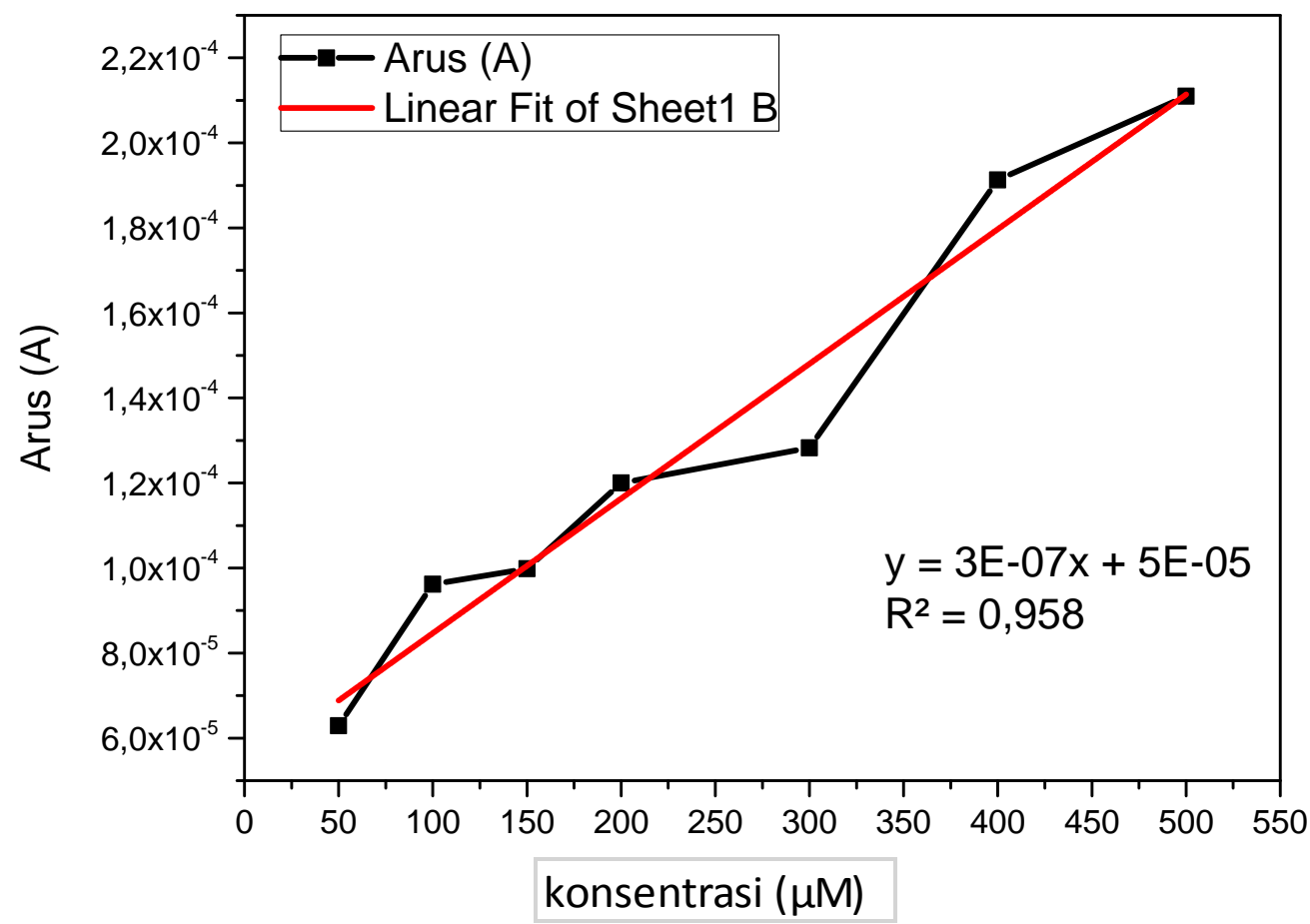

Gambar 5. Hubungan konsentrasi sampel dan arus yang dihasilkan dengan sensor NPAg.

Pada Gambar 5 merupakan grafik hubungan linieritas antara konsentrasi acetaminophen terhadap arus yang dihasilkan menggunakan sensor NPAg. Adapun persamaannya yaitu $\mathrm{Y}=\mathrm{ax}$ $+\mathrm{b}$, dimana $\mathrm{Y}=$ absorban; $\mathrm{x}=$ konsentrasi; $\mathrm{a}=$ koefisien regresi (slope); dab $\mathrm{b}=$ intercep [14]. Pada konsentrasi $50 \mu \mathrm{M}$, arus yang dihasilkan sekitar $1,09 \times 10^{-4}$ A. Pada konsentrasi $100 \mu \mathrm{M}$ arus yang dihasilkan menurun yaitu sekitar $1,08 \times 10^{-4} \mathrm{~A}$. Pada konsentrasi $150 \mu \mathrm{M}$ arus yang dihasilkan meningkat sebesar $1,23 \times 10^{-4}$ A. Dapat diperhatikan bahwa konsentrasi sampel dan arus yang dihasilkan menunjukkan garis lurus atau linier. Setiap penambahan konsentrasi sampel maka arus yang dihasilkan meningkat pula. Dari grafik linieritas dapat pula diketahui sensitivitas dari sensor tersebut. Adapun persamaan dari sensitivitas yaitu [15]:

Sensitivitas $=\frac{\text { Slope }}{A}$

Keterangan:

Slope $=$ kemiringan kurva standar

$\mathrm{A} \quad=$ luas permukaan elektroda $\left(\mathrm{cm}^{2}\right)$

\subsubsection{Analisis Bentuk Morfologi Karbon dan NPAg}

Analisis bentuk morfologi NPAg menggunakan Scanning Electron Microscopy (SEM). Karakterisasi menggunakan SEM juga dapat memberikan informasi mengenai ukuran partikel dari NPAg itu sendiri. Hasil yang diperoleh menunjukkan bentuk morfologi NPAg ditunjukkan pada Gambar 6. 


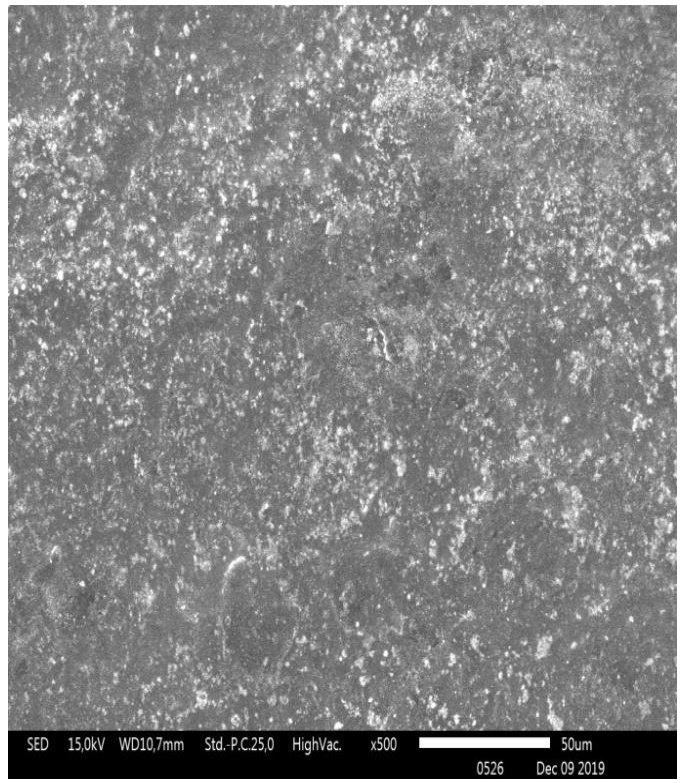

(a)

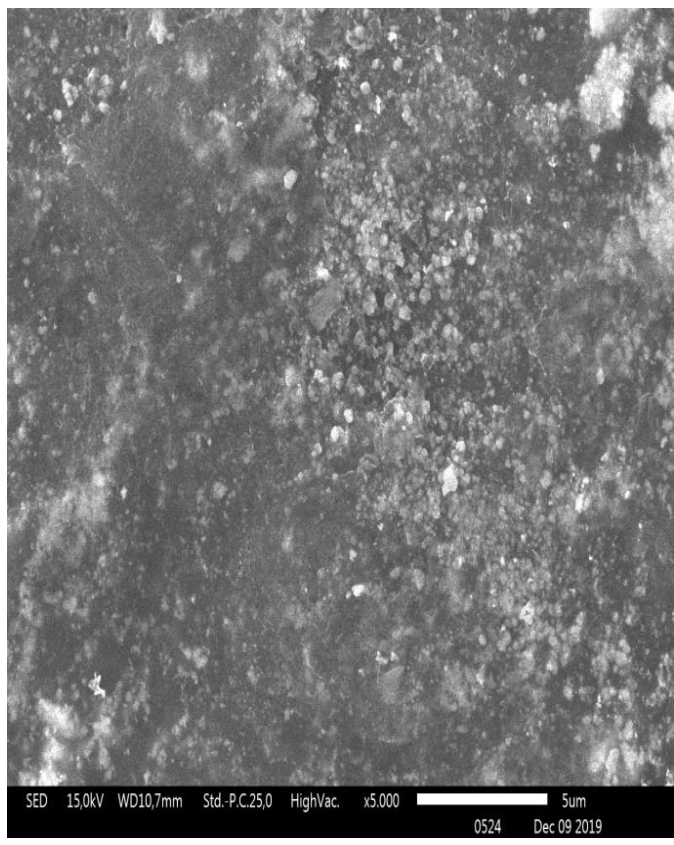

(c)

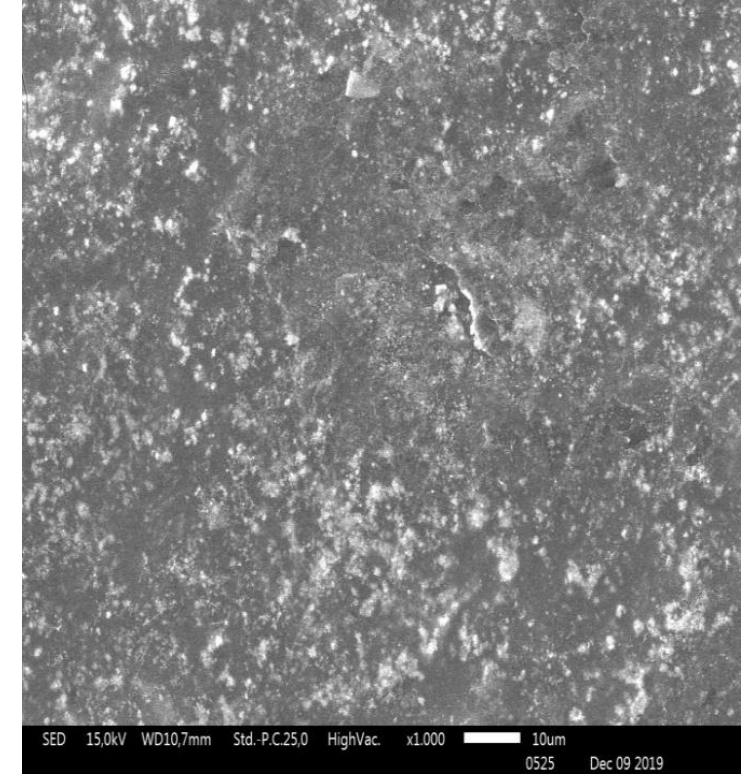

(b)

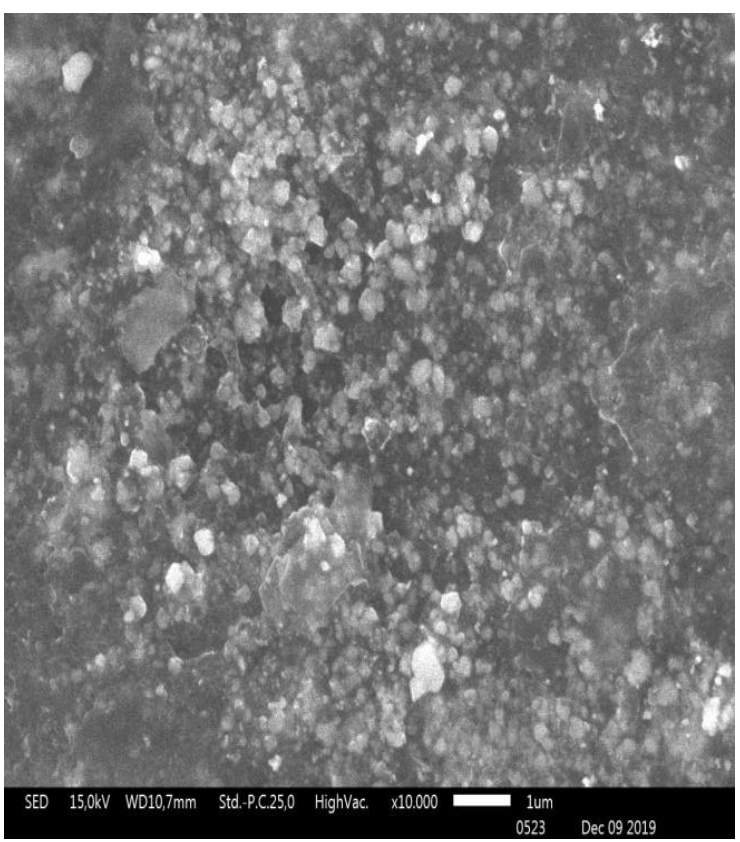

(d)

Gambar 6. Hasil data SEM NPAg (a) perbesaran 500, (b) perbesaran 1000, (c) perbesaran 1000, dan (d) perbesaran 10000.

Dapat dilihat pada Gambar 6 (a) dan (b) morfologi permukaan NPAg memiliki pori yang besar karena ukuran partikel kecil, semakin kecil ukuran partikel maka semakin besar pori yang terlihat begitupun sebailiknya, pada Gambar 6 (c) dan (b) morfologi permukaannya memiliki pori yang kecil karena ukuran partikelnya besar [16]. Permukaan yang memiliki pori yang banyak dapat menjadi tempat aseptor dengan baik dan proses transfer elektronnya dapat terjadi dengan baik [17]. 


\subsubsection{Karakterisasi NPAg dengan FTIR}

Karakterisasi NPAg dengan FTIR bertujuan untuk mengetahui gugus fungsi yang teridentifikasi dalam NPAg. Gambar 7 menunjukkan spektrum transmitansi IR NPAg.

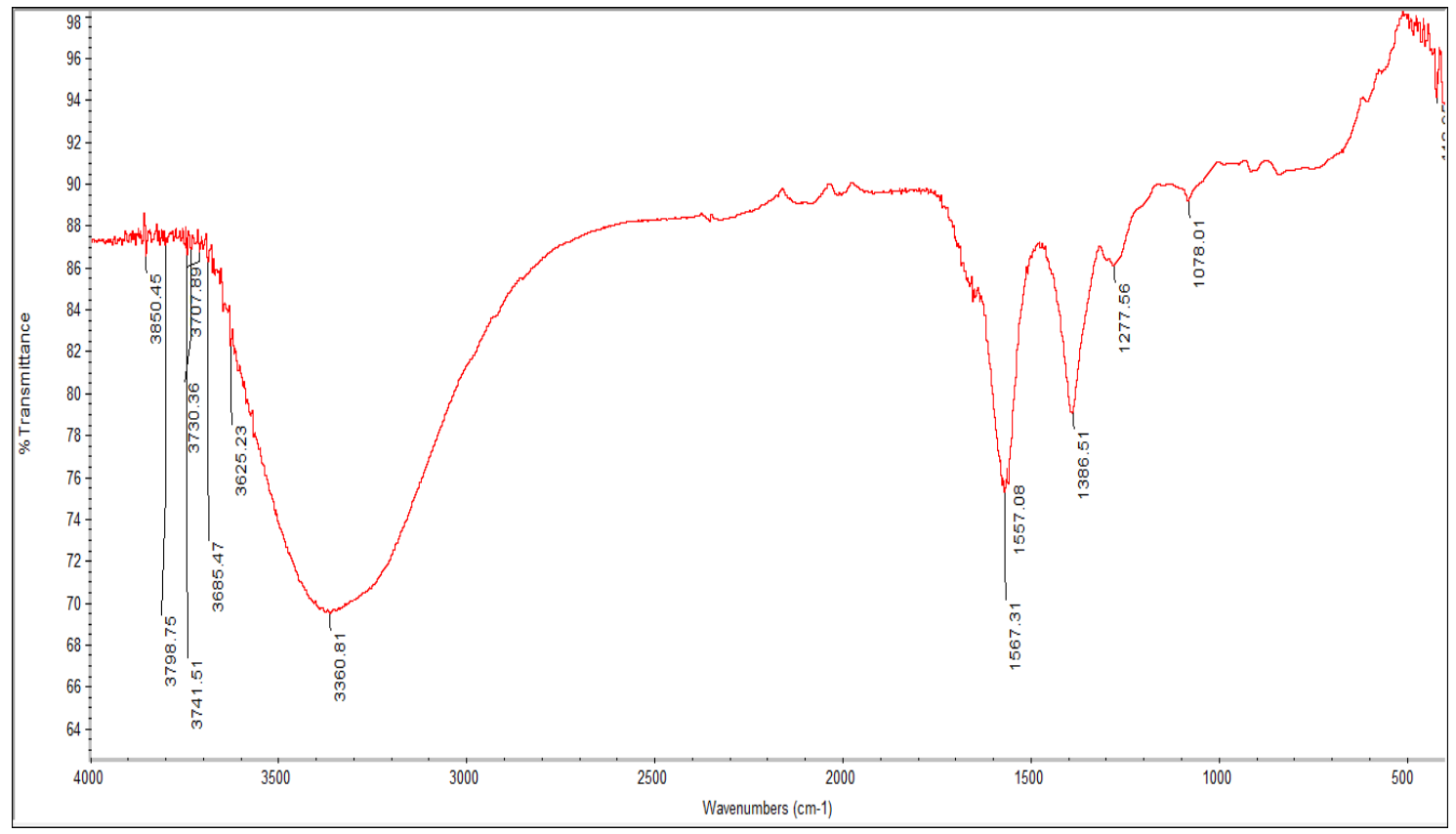

Gambar 7. Karakterisasi FTIR dengan NPAg

Terdapat empat gugus fungsi yang teridentifikasi pada karakterisasi FTIR dengan NPAg diantaranya gugus fungsi C-O terjadi pada bilangan gelombang $1078,01 \mathrm{~cm}^{-1}$ sampai 1277,56 $\mathrm{cm}^{-1}$. Gugus fungsi $\mathrm{NO}_{2}$ yang mempunyai intensitas kuat dan tipe senyawa nitro terjadi pada bilangan gelombang $1557,08 \mathrm{~cm}^{-1}$ sampai $1567,31 \mathrm{~cm}^{-1}$. Gugus fungsi $\mathrm{N}-\mathrm{H}$ yang mempunyai intensitas sedang dan tipe senyawa amina terjadi pada bilangan gelombang $3360,81 \mathrm{~cm}^{-1}$. Gugus fungsi C-H terjadi pada bilangan gelombang $1386,51 \mathrm{~cm}^{-1}[18]$.

\section{KESIMPULAN}

Fabrikasi elektroda sensor elektrokimia telah berhasil dilakukan. Pengujian kinerja kestabilan elektroda referensi $\mathrm{Ag} / \mathrm{AgCl}$ dengan perbandingan elektroda pabrikan, memperlihatkan bahwa elektroda referensi $\mathrm{Ag} / \mathrm{AgCl}$ yang telah dibuat memiliki tingkat kestabilan yang cukup baik dengan tegangan $<100 \mathrm{mV}$. Nanopartikel perak yang disintesis dapat meningkatkan konduktivitas atau laju elektron transfer pada permukaan karbon atau elektroda kerja dengan pengujian siklik voltametri yang ditandai dengan munculnya peak oksidasi acetaminophen dengan rentang tegangan 0,2 hingga $0,4 \mathrm{mV}$ dan arus yang dihasilkan pada setiap penambahan konsentrasi akan meningkat pula yang artinya penambahan konsentrasi berbanding lurus terhadap arus yang dihasilkan. Karakterisasi SEM menunjukkan morfologi permukaan NPAg memiliki pori yang kecil karena ukuran partikelnya yang besar sehingga porinya terlihat kecil. Sedangkan pada karaktersisasi menggunakan FTIR menghasilkan empat macam gugus fungsi diantaranya gugus fungsi $\mathrm{C}-\mathrm{O}$ yang mempunyai intensitas kuat, gugus fungsi $\mathrm{C}-\mathrm{H}$, gugus fungsi $\mathrm{NO}_{2}$, dan gugus fungsi $\mathrm{N}-\mathrm{H}$. 


\section{SARAN}

Dari hasil penelitian ini penulis berharap akan berlanjut, dengan memanfaatkan tegangan yang sudah ada pada penelitian ini yaitu dengan cara merancang alat sensor elektrokimia berbasis mikrokontroller untuk mendeteksi acetaminophen atau pembuatan sensor untuk mendeteksi acetaminophen.

\section{UCAPAN TERIMA KASIH}

Penulis mengucapkan terima kasih kepada PPET-LIPI yang telah menyediakan laboratorium serta alat dan bahan sehingga kegiatan penelitian ini dapat dilakukan, dan laboratorium Advanced Functional Materials (AFM) Departemen Teknik Fisika ITB yang telah menyediakan laboratorium dalam pengujian siklik voltametri.

\section{DAFTAR PUSTAKA}

[1] I. Seikhshoaie, F. Garkani dan H. Beitollahi. "An Electrochemical Acetaminophen Sensor Based on $\mathrm{La}^{3+} / \mathrm{Co}_{3} \mathrm{O}_{4}$ Nanoflowers Modified Graphite Screen Printed Electrode Architeccture". Original Article, vol. 10, no. 2, pp. 154-162, 2019.

[2] D. Apriandanu, S. Wahyuni, S. Hadisaputro dan Harjono. "Sintesis Nanopartikel Perak Menggunakan Metode Poliol Dengan Agen Stabilisator Polivinilalkohol (PVA)". Jurnal MIPA, vol. 36, no, 2, pp.157-168, 2013.

[3] A. Mazzonello, V. V. Valdramidis, C. Farrugia, J. N. Grima dan R. Gatt. "Synthesis 'and Characterization of Silver Nanoparticles". International Journal of Modern Engineering Reseacrh (IJMER), vol. 7, no. 3, pp. 41-49, 2017.

[4] S. Ahmad, M. Ahmad, B. L. Swami dan S. Ikram. "A Review on Plants Extract Mediated Synthesis of Silver Nanoparticles for Antimocrobial Applications: A Green Expertise". Journal of Advanced Research, no. 7, pp. 17-28, 2016.

[5] S. L. A. Paluri, M. L. Edwards, N. H. Lam, E. M. Williams, A. Meyerhoefer dan I. E. P. Sizemore . "Introduction "Green" and "Nongreen" Aspects of Noble Metal Nanoparticles Synthesis: An Inquiry-Based Laboratory Experiment for Chemistry and Engineering Students". Journal Chemical Education, no. 92, pp.350-354, 2015.

[6] S. Yesilot dan C. Aydin. "Silver Nanoparticles; A New Hope In Cancer Therapy?". Eastern Journal of Medicane, vol. 24, no. 1, pp. 111-116, 2019.

[7] I. Ristian, S. Wahyuni dan K. I. Supardi. "Kajian Pengaruh Konsentrasi Perak Nitrat Terhadap Ukuran Partikel Pada Sintesis Nanopartikel Perak". Indonesian Journal of Chemical Science, vol. 3, no. 1, pp. 7-11, 2014.

[8] M. Akter, et. al. "A Systematic Review on Silver Nanoparticles-Induced Cytoxity: Physicochemical Properties and Perspectives". Journal of Advanced Research, no. 9, pp. 116, 2018.

[9] M. Khairy, B. C. Mahmoud dan C. E. Banks. "Simultaneous Determination of Codeineanditsco-Formulated Drugs Acetaminophen and Caffeine by Utilising Cerium Oxide Nanoparticles Modified Screen Printed Electrodes". Sensors and Actuators B: Chemical, no. 259, pp. 142-254, 2018.

[10] N. K. Isvani, A. Mulyasuryani dan S. Prasetyawan. "Jurnal Kimia Valensi: Jurnal Penelitian dan Pengembangan Ilmu Kimia".Kinerja Biosensor Konduktometri Berbasis (Screen Printed Carbon Electrode) SPCE-Kitosan Untuk Deteksi Diazinon, Malatinon, Klorpirifos dan Profenofos, vol. 1, no. 2, pp. 83-90, 2015.

[11] I. Seikhshoaie, F. Garkani dan H. Beitollahi. "Original Article". An Electrochemical Acetaminophen Sensor Based on $\mathrm{La}^{3+} / \mathrm{Co}_{3} \mathrm{O}_{4}$ Nanoflowers Modified Graphite Screen Printed Electrode Architeccture, vol. 10, no. 2. pp. 154-162, 2019. 
[12] A. Debataraja, Hiskia dan R. V. Manurung. "Fabrikasi Biotranduser Dengan Metode Amperometrik Studi Awal Sensor Unsur Hara Tanah". Prosiding Conference on SmartGreen Technology in Electrical and Information Systems, pp. 121-124, 2013.

[13] K. Khaira. "Analisis Kadar Tembaga (Cu) dan Zeng $(\mathrm{Zn})$ dalam Air Minum Isi Ulang Kemasan Galon di Kecamatan Lima Kaum Kabupaten Tanah Datar". Jurnal Saintek, vol. VI, no. 2. pp. 116-123, 2014

[14] A. Mulyasuryani, R. T. Tjahhanto dan R. Andawiyah. "Simultaneous Voltammetric Detection of Acetaminophen and Caffeine Base on Cassava Starch- $\mathrm{Fe}_{3} \mathrm{O}_{4}$ Nanoparticles Modified Glassy Carbon Electrodes”. Journal Chemosensors, vol. 7, no. 49, pp. 1-11, 2019.

[15] J. C. Miller, dan J. N. Miller, 1991, Statistic and Chemmometrics for Anatycal Chemistry, Six Edition. Ashford Colour Press. UK.

[16] T. Rahman, M. A. Fadhlulloh, A. B. D. Nandiyanto dan A. Mudzakir. "Review: Sintesis Karbon Nanopartikel”. Integr. Proses, vol. 5, pp. 120-131, 2015.

[17] E. Y. Lembang, dan M. M. Zakir. Sintesis Nanopartikel Perak dengan Metode Reduksi Menggunakan Bioreduktor Ekstrak Daun Ketapang, pp. 1-11, 2016.

[18] P. Harry, dan S. T. Limbong. "Identifikasi Gugus Fungsi Senyawa Kimia Pulp Batang Pisang Berdasarkan Spektrum FTIR”. Jurnal Teknik dan Teknologi, vol. 12, no. 23, 2017. 